\title{
Lab-Scale Performance Evaluation of Vertical Flow Reed Beds for the Treatment of Chlorobenzene Contaminated Groundwater
}

\author{
Gerard Merlin ${ }^{1 *}$, Nathalie Cottin ${ }^{2}$ \\ ${ }^{1}$ Laboratoire LOCIE CNRS UMR, Université de Savoie, Le Bourget du Lac, France; ${ }^{2}$ Laboratoire LCME; Université de Savoie, Le \\ Bourget du Lac, France. \\ Email: *gerard.merlin@univ-savoie.fr
}

Received June $1^{\text {st }}, 2012$; accepted July $2^{\text {nd }}, 2012$; accepted August $2^{\text {nd }}, 2012$

\begin{abstract}
Chlorinated Benzenes (CBs) that were released into the environment contaminate groundwater at many existing and former industrial sites. A research program was initiated to investigate the ecoremediation of $\mathrm{CBs}$ contaminated groundwater using subsurface flow constructed wetlands. Four lab-scale experiments were performed to evaluate removal efficiency with different operation conditions. The first experiment was achieved with two different solid-state materials: a peat and a lava stone (pozzolana). In order to stimulate biological activity, organic matter coming from an aged Vertical Flow Constructed Wetlands (VFCW) was added to the media. Mass balance was determined to assess the fate of these pollutants in this system. The biofiltres of the second experiment were constructed with the same materials but bioaugmentation was realized by adding organic matter of VFCW or by bacteria inoculums. Peat and pozzolana biofiltres planted with Phragmites australis constituted the third experiment to evaluate the effect of plants. Bioaugmentation was constituted by the addition of OM coming from aged VFCW. Compost mixed with pozzolana was the solid-state material of the fourth experiment. Columns were made of two stages. The first stage was unplanted and the second stage was planted with Phragmites. Peat has been replaced by compost, a renewable material. Lab-scale biofiltres remove CBs with an efficiency of 70\% - 99\%, depending on studied media and conditions. Greater efficiency was observed with bioaugmented media. Volatilization was very low $(<0.2 \%)$ and the detection of chlorides in water indicated the occurrence of biodegradation. The experiments have shown that organic solid-state materials (compost or peat) are useful for groundwater remediation, with higher treatment efficiency than pozzolana material. Bioaugmentation increased biological activity. Clogging of biofiltres have been observed and can be reduced by the presence of plants or by a resting period of 14 - 21 days (requiring alternative feedings on several filters).
\end{abstract}

Keywords: Organochlorine; Constructed Wetlands; Phytoremediation; Bioaugmentation; Micropollutants

\section{Introduction}

Chlorinated Benzenes (CBs) are widely used as chemical intermediates and solvents across industry or as pesticides. Halogenated organic compounds that were released into the environment contaminate groundwater at many existing and former industrial sites. Concentrations of CBs in the environment vary, ranging from 0.07 to 34.79 $\mathrm{ng} \cdot \mathrm{L}^{-1}$ in water from industrial catchments [1]. Groundwater at an industrial site is contaminated with CBs in the 1 to $15 \mathrm{ppm}$ range including 1,2,4-trichlorobenezene (TCB), 1,2-dichlorobenzene (DCB), 1,3-DCB, 1,4-DCB, chlorobenzene (CB), benzene, trichloroethene (TCE), and cis-1,2-dichloroethene (cDCE) with other contaminants hexachlorocyclohexane $(\mathrm{HCH})$ and $\gamma$ - $\mathrm{HCH}$ (i.e.,

${ }^{*}$ Corresponding author. lindane) in the range of 0.3 to $0.5 \mathrm{ppm}$ [2]. Lindane designed to control a wide range of agricultural, horticultural and public health pests is one of the most extensively used.The total concentrations of $\mathrm{CBs}$ in the soil of an agricultural field near a chemical plant in Chinaranged from 71.06 to $716.57 \mathrm{ng} \cdot \mathrm{g}^{-1}$, with a mean concentration of $434.93 \mathrm{ng} \cdot \mathrm{g}^{-1}$. The main components of CBs in soil samples were dichlorobenzenes (DCBs), trichlorobenzenes (TCBs) and tetrachlorobenzenes (TeCBs), while for single congeners, 1,2,4-TCB had the highest concentration, which ranged from 13.21 to $210.35 \mathrm{ng} \cdot \mathrm{g}^{-1}$ with a mean concentration of $111.89 \mathrm{ng} \cdot \mathrm{g}^{-1}$ [3]. Ecoremediation (ERM) comprises methods of protection or restoration of the environment by means of natural processes existing in ecosystems. The establishment of ERM systems provides sustainable environmental management solutions 
that contribute to the preservation of biodiversity and pollution reduction, increase the quality of water and soil, and can be applied in protected and sensitive areas. The functions of ERM are based on aquatic, waterside, and wetland ecosystems, and are characterized by high retention capacity, flooding prevention, and reduction of specific physical, chemical, and toxic pollution [4]. The last few years, interest has grown in using constructed wetlands (a type of ERM) as remediation process for the removal of recalcitrant organic substances from contaminated waste and groundwater, including chloroaromatics [5], chlorinated benzenes [6,7], dichloroethene [8] or benzene $[9,10]$. Therefore, constructed wetlands are more economic in term of energy consumption and operational costs; these approaches are preferred for groundwater remediation. Many of these systems use the horizontal subsurface flow, but an interesting alternative is the vertical flow with alternative feedings that provide oxygen, thus creating an aerobic environment. This process supports microbial communities, which can degrade organic pollutants and supports biotransformation processes [11] and microbial degradation of CBs under aerobic conditions is fast and efficient [12]. Studies on lowchlorinated benzenes are rare [7]. So a research program was initiated to investigate the ecoremediation of CBs contaminated groundwater using subsurface flow reed beds. A pilot-scale was located on a French industrial site. To have better knowledge on the removal of $\mathrm{CBs}$ and to know the effects of pollutants on biological activities, lab-scale experiment were performed with different filling materials and different configurations.

\section{Material and Methods}

\subsection{Chemicals}

Monochlorobenzene (MCB), 1,3-Dichlorobenzene (1,3-
DCB), 1,4-Dichlorobenzene (4,4-DCB), 1,2,3-Trichlorobenzene (1,2,3-TCB), 1,2,4-Trichlorobenzene (1,2,4 TCB), Tetrachlorobenzene (TeCB) and Hexachlorohexane $(\mathrm{HCH})$ were purchased from Sigma (98\% purity). The stock solution was prepared in dimethylsulfoxide (DMSO) obtained from Fisher Scientific, which is added to the tap water $(0.1 \%)$.

\subsection{Experimentation}

Four lab-scale experiments were performed (Table 1).

1) The first experiment was achieved with two different solid-state materials: a peat and a lava stone (pozzolana). In order to stimulate biological activity, organic matter coming from an aged Vertical Flow Constructed Wetlands (VFCW) was added to the media. Biofiltres were contaminated with $3 \mathrm{CBs}$ (pollutants at higher concentrations found in the polluted groundwater studied). Mass balance was determined in order to assess the fate of these pollutants in this system [13].

2) The biofiltres of the second experiment were constructed with the same materials but bioaugmentation was realized by adding organic matter of VFCW or by bacteria inoculums. Biofiltres were contaminated with 7 CBs (most representative of the contaminated groundwater studied). Mass balance was determined to confirm previous results.

3) Peat and pozzolana biofiltres planted with Phragmites australis constituted the third experiment to evaluate the effect of plants. Bioaugmentation was constituted by the addition of OM coming from aged VFCW.

4) Compost mixed with pozzolana (to maintain the hydraulic conductivity) was the solid-state material of the fourth experiment. Columns were made of two stages. The first stage was unplanted and the second stage was planted with Phragmites. Peat has been replaced by

Table 1. Experiments description.

\begin{tabular}{|c|c|c|c|c|}
\hline EXPERIMENT & 1 & 2 & 3 & 4 \\
\hline FILLING MATERIALS & Peat or Pozzolana & Peat or Pozzolana & Peat or Pozzolana & Compost + Pozzolana $(30 \%)$ \\
\hline BIOAUGMENTATION & $\mathbf{O M}^{*}$ & Bacteria or OM & $\mathrm{OM}$ & Bacteria \\
\hline POLLUTANTS & $\begin{array}{c}3 \text { CBs: }(1.3-\mathrm{DCB} ; 1.2 .3-\mathrm{TCB} ; \\
1.2 .4-\mathrm{TCB})\end{array}$ & 7 CBs: & $\begin{array}{l}\text { CB; } 1.3-\mathrm{DCB} ; 1.4-\mathrm{D} \\
\text { 1.2.4-TCB; TeCB; }\end{array}$ & $\begin{array}{l}\mathrm{CB} ; 1.2 .3-\mathrm{TCB} \\
\mathrm{ICH})\end{array}$ \\
\hline CBs LOADING $\left(\mathrm{mg} \cdot \mathrm{m}^{-2} \cdot \mathrm{d}^{-1}\right)$ & 1696 & 1350 & 2160 & 1350 \\
\hline \multirow[t]{2}{*}{ Configuration } & unplanted & & \multicolumn{2}{|r|}{ planted } \\
\hline & \multicolumn{2}{|l|}{1 stage } & \multicolumn{2}{|r|}{2 stages } \\
\hline OPERATION TIME & 4 months & 6 months & 5 months & 7 months \\
\hline
\end{tabular}

OM: Organic Matter coming from a vertical flow constructed wetland. 
compost (renewable material less expensive) and pozzolana has been added up to $30 \%$ to maintain mechanical properties and the hydraulic conductivity.

\subsection{Filling Materials}

The filling materials are the support of biofilm development and they adsorb the organic pollutants. Different filling materials were used:

- An inorganic material:pozzolana that is a lavastone

- Two organic materials: peat and green compost.

These filling materials differ in term of porosity, density, hydraulic conductivity and organic carbon content [13]. Organic and inorganic materials have very different physicochemical properties (Table 2). For example, the content of organic carbon reach $20 \%$ for the peat while less than $1.5 \%$ for pozzolana.

Tap water spiked by CBs was added at the top of biofiltres, with alternative feedings and different pollutants daily specific loading rates (Table 1). Concentrations for CBs were respectively: $50 \mu \mathrm{g} \cdot \mathrm{L}^{-1}$ for MCB; 700 $\mu \mathrm{g} \cdot \mathrm{L}^{-1}$ for $1,3-\mathrm{DCB}, 120 \mu \mathrm{g} \cdot \mathrm{L}^{-1}$ for $1,4-\mathrm{DCB} ; 3000$ $\mu \mathrm{g} \cdot \mathrm{L}^{-1}$ for $1,2,3-\mathrm{TCB} ; 8500 \mu \mathrm{g} \cdot \mathrm{L}^{-1}$ for $1,2,4-\mathrm{TCB} ; 300$ $\mu \mathrm{g} \cdot \mathrm{L}^{-1}$ for $1,2,3,4-\mathrm{TCB}$ and $50 \mu \mathrm{g} \cdot \mathrm{L}^{-1}$ for Lindane.

Different measurements were realized to determine:

- removal efficiency of CBs AND mass balance to assess the part of volatilization, sorption, leaching and degradation;

- biofilm development and clogging using ATP and EPS determination;

- effluent toxicity using the Vibrio fisheri bioluminescence inhibition test.

\subsection{CB Analysis}

Pollutants were extracted from a sample volume of 100 $\mathrm{mL}$ of aqueous effluents and analysed using solid phase extraction (SPE) and HPLC methods [13]. At the end of the experiments, $\mathrm{CB}$ concentrations at different depths of columns were determined by Soxhlet extraction. To determine the volatilization of pollutants, each column was placed in a close chamber during $1 \mathrm{~h}$ as described in

Table 2. Main physicochemical properties of filling materials.

\begin{tabular}{ccc}
\hline & PEAT/COMPOST & POZZOLANA \\
\hline$\varepsilon(\%)$ & $49 \pm 20$ & $65 \pm 20$ \\
$\rho\left(\mathrm{g} \cdot \mathrm{L}^{-1}\right)$ & $450 \pm 20$ & $2200 \pm 100$ \\
$\mathrm{~K}\left(\mathrm{~m} \cdot \mathrm{s}^{-1}\right)$ & $8.0 \mathrm{E}-6$ & $14.1 \mathrm{E}-2$ \\
OC $(\%)$ & $17-20$ & 1.5 \\
\hline
\end{tabular}

$\varepsilon$ : porosity, $\rho$ : bulk density, K: hydraulic conductivity, OC: organic carbon content. previous study [13] (Cottin and Merlin, 2010).

\subsection{ATP Measurement}

ATP has previously been used to estimate the amount of biomass present in groundwater, drinking water, and biofilms. Total Control Technology from LuminUltra TM (TCB-50 Total Control BWWT 50, Aqua-Tools, France) is based on the measurement of ATP. ATP is a direct and interference-free indicator of living biomass. Total ATP (tATP) is the measurement of all ATP, including both intracellular (cATP) and extracellular ATP (dATP). cATP provides a direct indication of living biomass energy level, which is directly related to living biomass concentration. dATP provides information relating primarily to the relative health of the biomass. LuminUltra'sdATP'M method is superior to competing methods in that it measures the total amount of extracellular ATP, not just free or soluble dATP. Detecting ATP directly offers a simple and rapid method for estimating the amount of active biomass present on the media.

tATP, dATP, and cATP are defined as:

$$
\begin{aligned}
& \mathrm{tATP}=\left(\mathrm{RLU}_{\mathrm{tATP}} / \mathrm{RLU}_{\text {ucl }}\right) \times 306 \\
& \left.\mathrm{dATP}=\mathrm{RLU}_{\mathrm{dATP}} / \mathrm{RLU}_{\text {uc1 }}\right) \times 101 \\
& \mathrm{cATP}=\mathrm{tATP}-\mathrm{dATP}
\end{aligned}
$$

RLU is the number of photons emitted by the LuminUltra ${ }^{\mathrm{TM}}$ method (tATPTM and dATPTM) and $\mathrm{RLU}_{\mathrm{uc} 1}$ is the number of photons emitted by the UltraCheck ${ }^{\mathrm{TM}} 1$ calibration.

\subsection{EPS Determination}

Bacteria growing in biofilms produce exopolymers that help them attach to surfaces, bind together, and protect them from the surrounding environment. Polysaccharides are the major component of exopolymers in biofilms and vary with increased environmental stress. This method developed by Rimington [14] employs the sulphuricorcinol as reactive substance. Four hundred microliters of an extract solution obtained by suspending 1 to $2 \mathrm{~g}$ of solid sample with $10 \mathrm{~mL}$ of phosphate buffer $\left(\mathrm{K}_{2} \mathrm{HPO}_{4}\right.$ $9.5 \mathrm{mg} \cdot \mathrm{L}^{-1}, \mathrm{KH}_{2} \mathrm{PO}_{4} 1.8 \mathrm{mg} \cdot \mathrm{L}^{-1}$ ) was introduced into a glass tube with $2 \mathrm{~mL}$ of sulfuric orcinol $\left(2 \mathrm{~g} \cdot \mathrm{L}^{-1}\right)$ and 2 $\mathrm{mL}$ of distilled water mixed for $30 \mathrm{~s}$ and then kept 15 $\min$ at $80^{\circ} \mathrm{C}$. They were cooled and placed in darkness for $45 \mathrm{~min}$. The sample was filtered through $0.2-\mu \mathrm{m}$ polyethersulfone filters to remove particles. The absorbance is measured at $420 \mathrm{~nm}$. Glucose was used to construct standard curves for polysaccharide concentration [15] with a limit of detection of $0.37 \mu \mathrm{g}$.

\subsection{Hydraulic Flow Determination}

Hydraulic flow was measured with flowmeters at the 
outlet of the columns.

Experimental conditions: Temperature was maintained at about $20^{\circ} \mathrm{C}-25^{\circ} \mathrm{C}$ with artificial light $(16: 8 \mathrm{~h}$ light: dark;) at $250 \mu \mathrm{E} \cdot \mathrm{m}^{-2} \cdot \mathrm{s}^{-1}$ (photosynthetically active radiation) and $35 \%-45 \%$ relative humidity.

\subsection{Scanning Electron Microscopy}

Scanning Electon microscopy has been used using method described by Fraser and Gilmour [16].

\section{Results}

\subsection{Fate of CBs}

Mass balance of the biofiltres was realized at the end of experiments, corresponding to 4 - 6 months of operation.

Lab-scale biofiltres remove CBs with an efficiency of $95 \%$ - 99\%, depending on studied media and conditions (Figure 1). Greater efficiency was observed with bioaugmented media. CBs removal efficiencies were $20 \%$ $35 \%$ higher than those observed with a pilot-scale horizontal subsurface constructed wetlands [7].

Volatilization was very low $(<0.2 \%)$ and the detection of chlorides in water indicated the occurrence of biodegradation. A low volatilization $(<2 \%-4 \%$ of the total amount removed) has also been measured with pilot- scale constructed wetlands [7,17]. A significant enhancing effect of plants on removal CBs or volatilization has not shown in experiment 4 with planted biofiltres as mentioned by literature $[6,7]$.

Concentrations of $\mathrm{CBs}$ in the pozzolana effluent reached $5 \%$ and was less than $1 \%$ for the peat or compost effluents while sorption of CBs on the filling materials reached $2 \%$ to $4 \%$ for the peat or compost biofiltresand CBs degradation was higher than $95 \%$ in this case.

The presence of plants does not change the fate of $\mathrm{CBs}$ due to certainly of their low biomass.

The concentration of sorbed CBs on the filling materials has been measured at different depth. High concentration of CBs have been observed in the filling materials and reached 300 to $5000 \mathrm{ppm}$ (Figure 2) while very low CBs concentrations have been measured in the second stage of reed beds pilots. Highly chlorinated benzenes are strongly affected by sorption and therefore accumulate in filling media of constructed wetlands [8].

However, the concentration of pollutants were 8 times lower in the biofiltres with bacteria where the concentration achieved $600 \mu \mathrm{g} / \mathrm{g}$ of DM against $5000 \mu \mathrm{g} / \mathrm{g}$ of DM in the non-bioaugmented biofiltres.

Positive effect of bioaugmentation has been observed with planted biofiltres as it has been observed in the

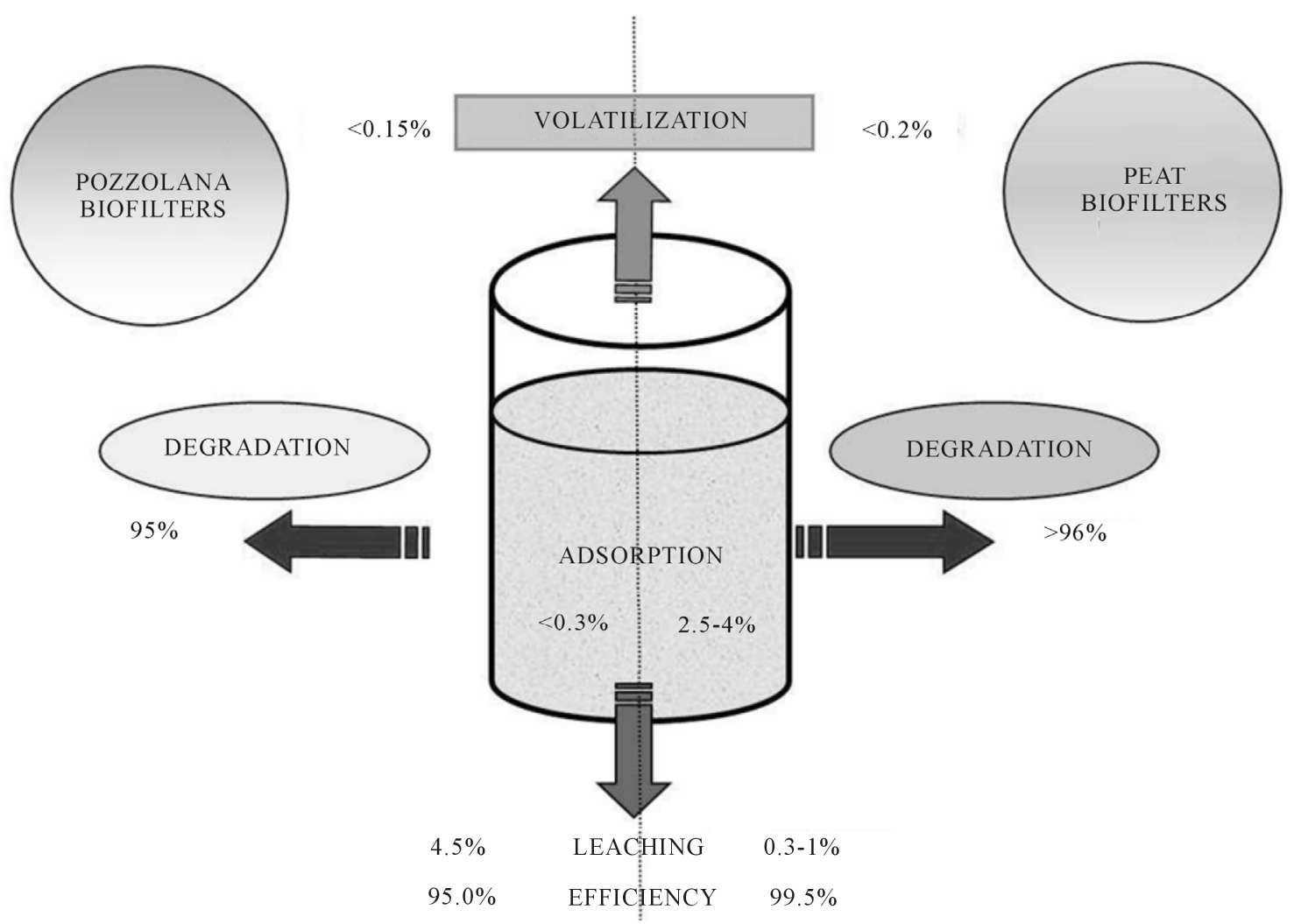

Figure 1. Fate of CBs in vertical flow reed beds lab-scale pilots. 

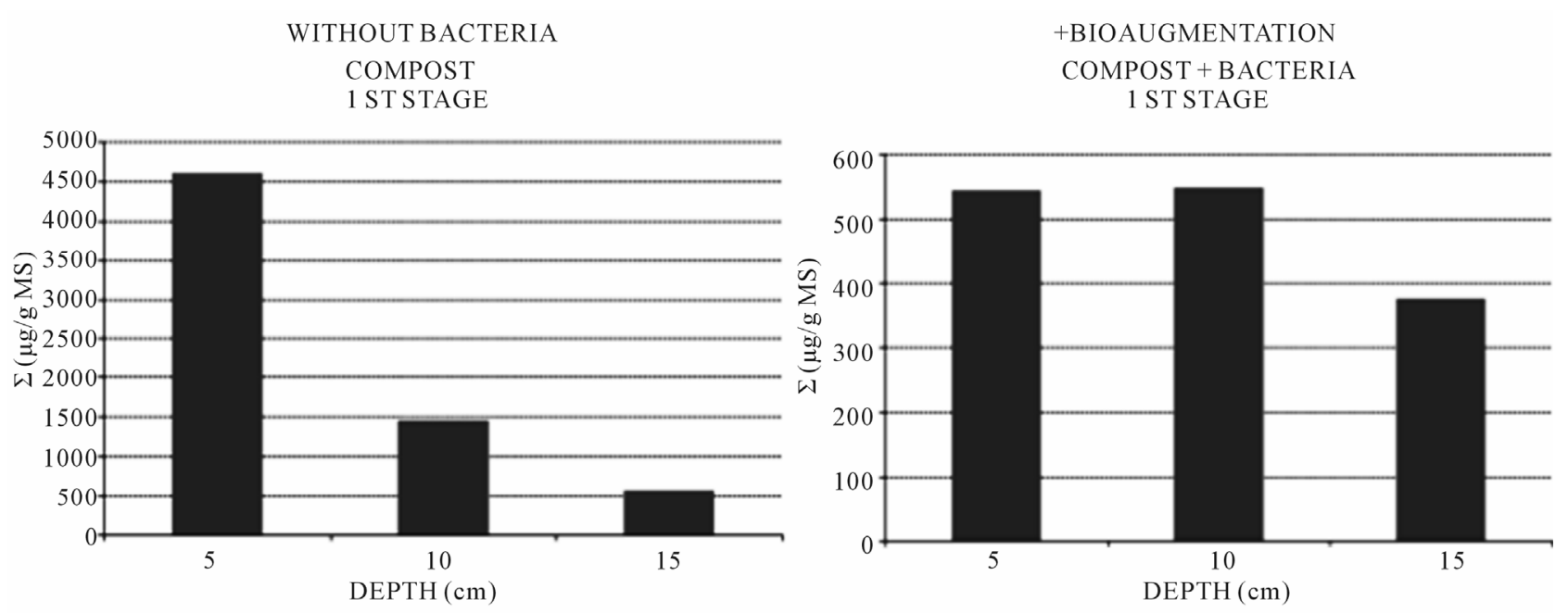

Figure 2. Adsorbed CBs vs depth, example of planted biofiltres pilots.

unplanted biofiltres. Large-scale production of bacterial consortia for remediation of chlorinated solvent-contaminated groundwater can be easily implemented for bioaugmentation in the vertical flow reed beds [18].

Unplanted and planted biofiltres can treat this pollution with high removal efficiency.

However, concentrations of CBs measured in pozzolana biofiltres effluent were higher than discharge river limits that can constitute a problem for its use on Industrial sites.

\subsection{Biofilm Development and ATP Contents}

The biofilm was distributed along a depth gradient with high activity at the top of the organic biofiltres while pozzolana biofiltres are more active at the bottom. Cellular ATP provides a direct indication of living biomass energy levelExtra-cellular ATP provides information to the relative health of the biomass. When biomass becomes unhealthy or dies, it releases ATP into the external environment. Therefore, higher dATP value is a direct result of biomass mortality. dATP values were less than $40 \%$ for the peat biofiltres (Figure 3), For pozzolana media, the dATP values were higher and reached $60 \%$ $80 \%$ in the different depth of the column. This result indicated an environmental stress for the pozzolana biofiltres where biomass became unhealthy or dies. dATP values were less than $20 \%$ in biofiltres with OM or bacteria addition. These results indicated the positive effect of bioaugmentation that enhanced the living biomass.

\subsection{Vibrio Fisheribioluminescence Inhibitiontest}

Spiked tap water has $50 \%$ of inhibition in average while controls have less than $10 \%$ of inhibition; contaminated biofiltres have an inhibition of about 20 to $50 \%$ which reached the same level of toxicity than the contaminated tap water (Figure 4).

However, variability in time was significant.

It is possible to conclude that the biofiltres have high removal efficiency but a residual effluent toxicity.

\subsection{EPS and Biofilm}

EPS has been determinate in all the experiments after a period of 3 - 6 months. Biomass produced EPS to protect them about environmental stress [19]. In experiment 4 with two stages of biofiltration, EPS concentration was higher in the 1st stage of contaminated biofiltres due to the pollutants that create achemical stress for the biofilm (Figure 5). Some strains of bacteria that were able to produce EPS could degrade aromatic compounds [20].

EPS concentration observations was confirmed by the measurement of dATP; $20 \%$ to $40 \%$ of dATP was observed in the first stage against less than $5 \%$ for the second stage, confirming a biomass unhealthy or dies due to pollutants exposition.

The addition of organic matter significantly increased biological activity. A clogging was observed at the end of all the experiments except experiment 4 with planted pilots. This clogging was due to biomass accumulation and EPS production. Decrease of efficiency of about $15 \%-25 \%$ has been observed with clogged biofiltres, except for bioaugmented solid-state materials. This phenomenon appeared later in the planted biofiltres according to roots which maintain the hydraulic conductivity [11].

\subsection{SEM}

Scanning Electronic Microscopy (SEM) has been used to illustrate the clogging (Figure 6). 

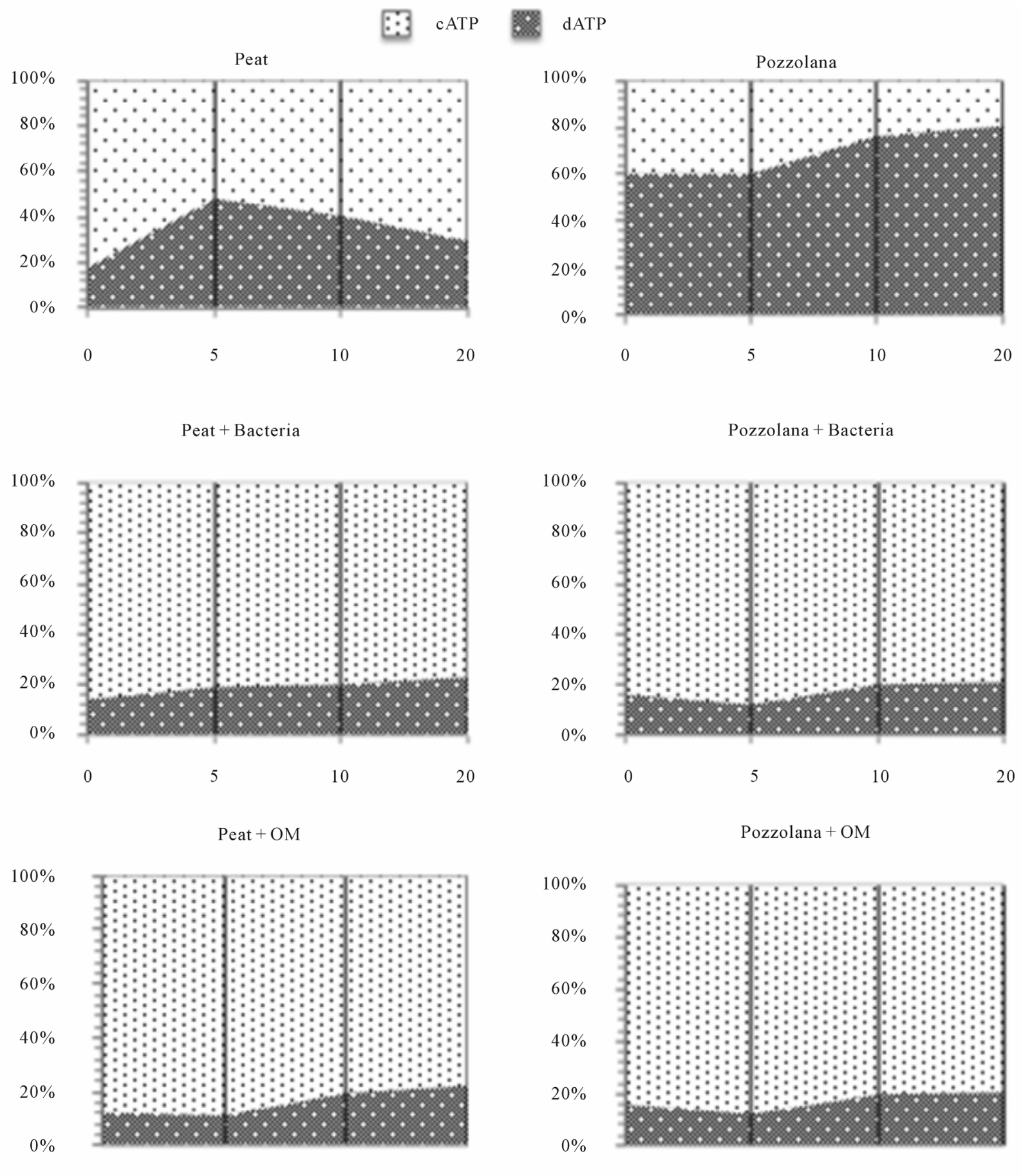

Figure 3. ATP vs depth.

\subsection{Hydraulic Flow Measurements}

The hydraulic conductivity was estimated by following flows after several rest periods without feedings in experiment 4 (Figure 7). After contaminated water flushes, without clogging, maxima flows were close to $1 \mathrm{~mL} \cdot \mathrm{s}^{-1}$ with a hydraulic residence time of some minutes. Flows in clogged biofiltres were less than $0.1 \mathrm{~mL} \cdot \mathrm{s}^{-1}$. Rest periods of 2 to 3 weeks were necessaries to recover the initial flows.

So, alternative feeding and rest periods on several biofiltres will be required to avoid clogging. 


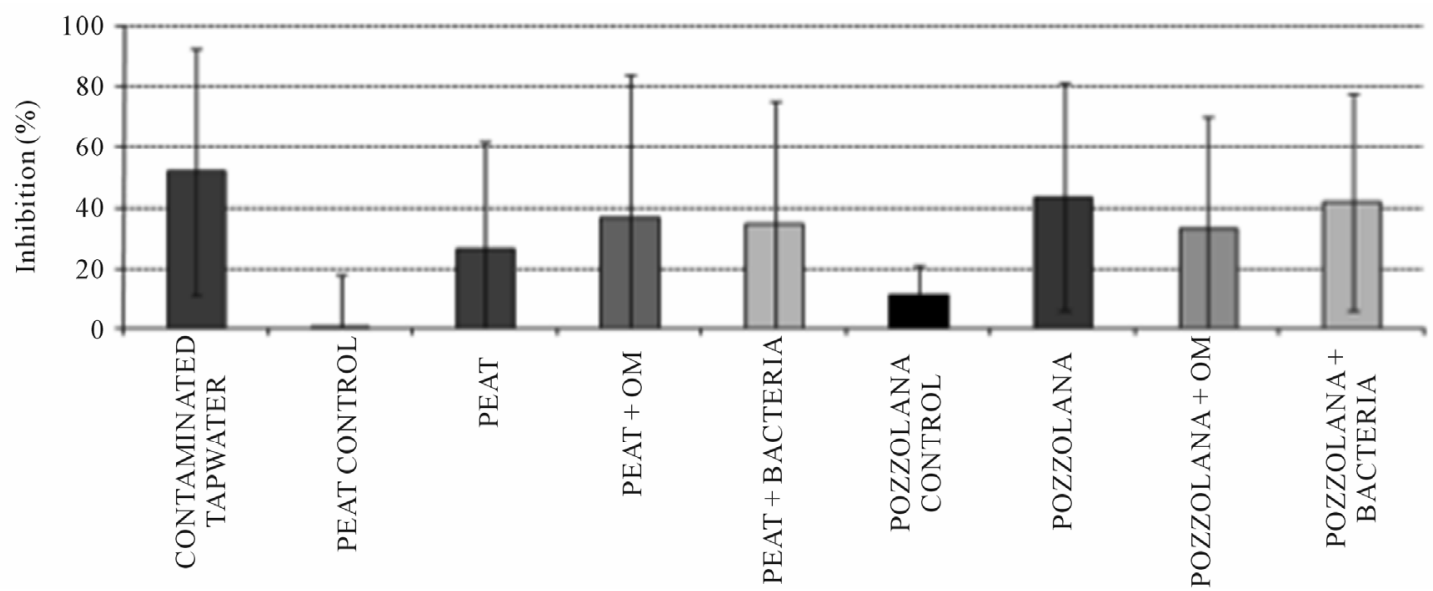

Figure 4. Inhibition of bioluminescence in Vibrio Fisherii test.

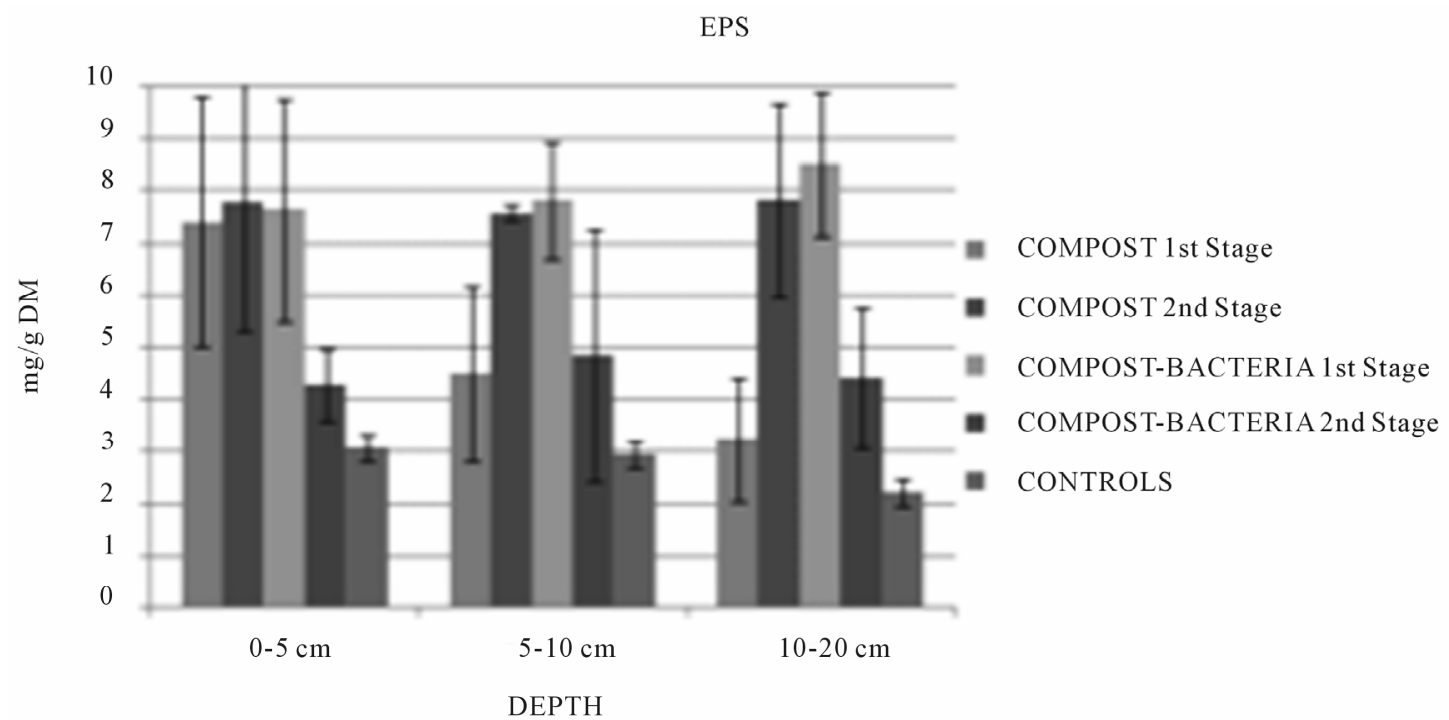

Figure 5. EPS concentration vs depth and stage, example of theexperiment 4.

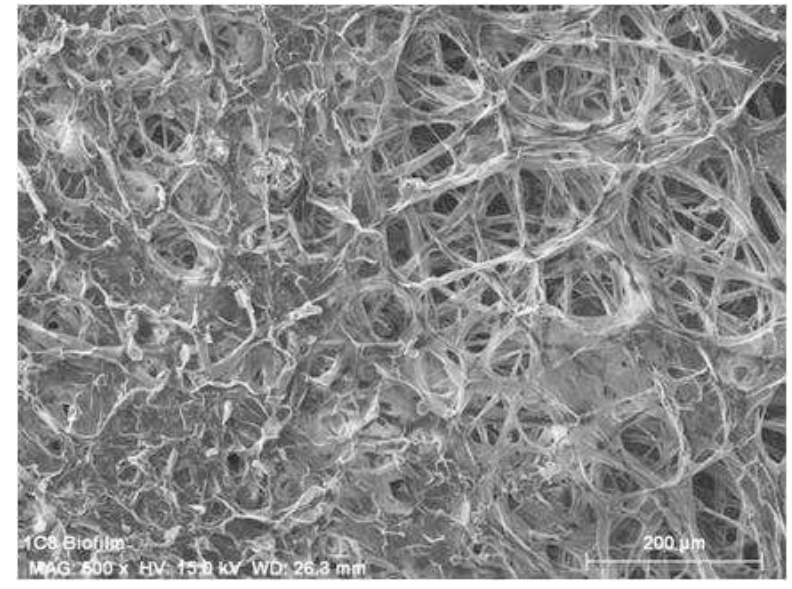

Figure 6. Scanning electron micrograph of extra-cellular material product by the biofilm of contaminated compost biofiltre.

\section{Conclusion}

These experiments have showed that organic solid-state materials (compost or peat) are useful for contaminated groundwater remediation, with higher treatment efficiency than pozzolana material. Vertical flow reed beds constructed with these filling materials have therefore a remarkable potential to remove halo-organic pollutants from contaminated water.

Bioaugmentation increased biological activity. Clogging of biofiltreshave been observed after several monthsand can be reduced by the presence of plants or by a resting period of 14 - 21 days (requiring alternative feedings on several filters).

\section{Acknowledgements}

This work is part of VALORSITE-PHYCO project funded 
COMPOST 1st stage

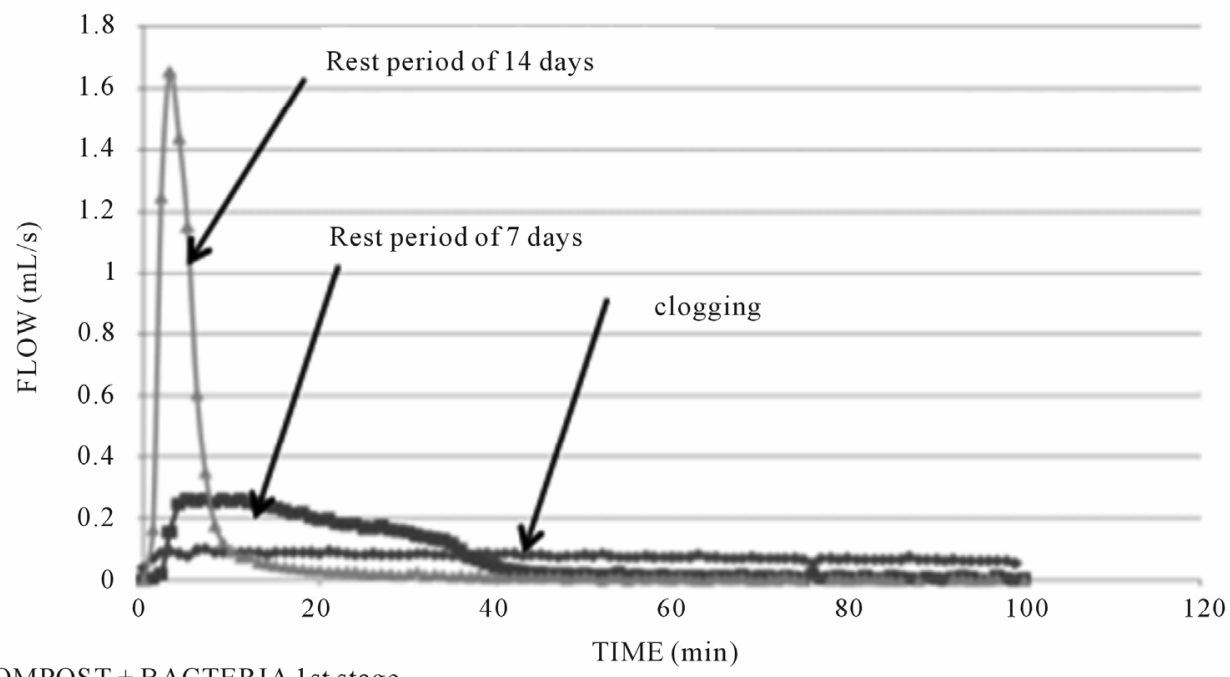

COMPOST + BACTERIA 1 st stage

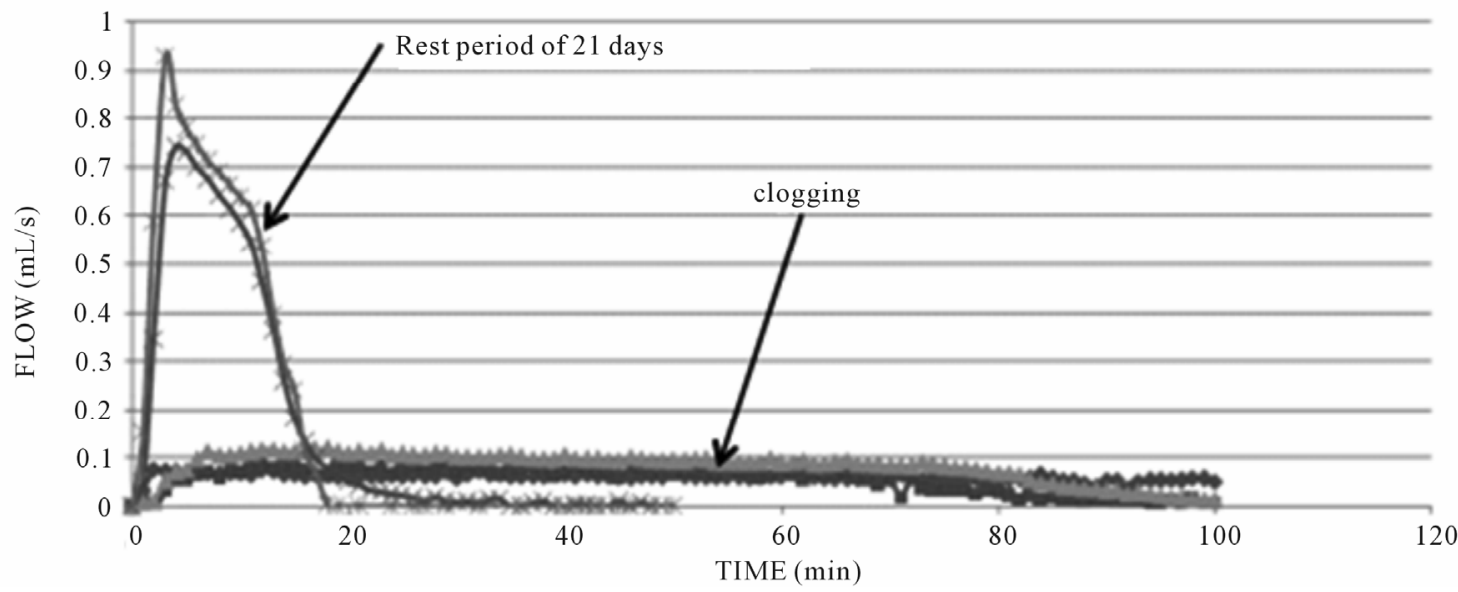

Figure 7. Outlet hydraulic flows after different rest periods in experiment 4.

by AXELERA and Région Rhône-Alpes.

\section{REFERENCES}

[1] A. A. Meharg, J. Wright and D. Osborn, "Chlorobenzenes in Rivers Draining Industrial Catchments," Science of the Total Environment, Vol. 251-252, 2000, pp. 243-253. doi:10.1016/S0048-9697(00)00387-9

[2] V. Elango, J. Cashwell and M. Bellotti, "Bioremediation of Hexachlorocyclohexane Isomers, Chlorinated Benzenes, and Chlorinated Ethenes in Soil and Fractured Dolomite," Bioremediation Journal, Vol. 14, No. 1, 2010 , pp. 10-27. doi:10.1080/10889860903463695

[3] Y. Song, F. Wang and Y. Bian, "Chlorobenzenes and Organochlorinated Pesticides in Vegetable Soils from an Industrial Site, China," Journal of Environmental Sciences-China, Vol. 24, No. 3, 2012, pp. 362-368. doi:10.1016/S1001-0742(11)60720-1

[4] T. G. Bulc and A. S. Slak, "Ecoremediations-A New Concept in Multifunctional Ecosystem Technologies for
Environmental Protection," Desalination, Vol. 246, No. 1-3, 2009, pp. 2-10. doi:10.1016/j.desal.2008.03.039

[5] E. S. Gilbert and D. E. Crowley, "Plants Compounds That Induce Polychlorinated Biphenyl Biodegradation by $\mathrm{Ar}$ throbacter sp. Strain B1B," Applied Environmental Microbiology, Vol. 63, 1997, pp. 1933-1938.

[6] M. Braeckevelt, G. Mirschel, A. Wiessner, M. Rueckert, N. Reiche and C. Vogt, "Treatment of ChlorobenzeneContaminated Groundwater in a Pilot-Scale Constructed Wetland," Ecological Engineering, Vol. 33, No. 1, 2008, pp. 45-53. doi:10.1016/j.ecoleng.2008.02.002

[7] M. Braeckevelt, M. Reiche, N, Trapp, S. Wiessner, A. Paschke, H. Kuschka and M. Kaestner, "Chlorobenzene Removal Efficiencies and Removal Processes in a Pilot-Scale Constructed Wetland Treating Contaminated Groundwater," Ecological Engineering, Vol. 37, No. 6, 2011, pp. 903-913. doi:10.1016/j.ecoleng.2011.01.014

[8] G. Imfeld, M. Braeckevelt, P. Kuschk and H. H. Richnow, "Monitoring and Assessing Processes of Organic Chemicals Removal in Constructed Wetlands," Chemosphere, 
Vol. 74, No. 3, 2009, pp. 349-362.

doi:10.1016/i.chemosphere.2008.09.062

[9] X. Tang, P. E. Eke, M. Scholz and S. Huang, "Processes Impacting of Benzene Removal in Vertical-Flow Constructed Wetlands," Bioresource Technology, Vol. 100, No. 1, 2009, pp. 227-234. doi:10.1016/j.biortech.2008.05.038

[10] T. F. Guerin, "Ex-Situ Bioremediation of Chlorobenzenes in Soil," Journal of Hazardous Materials, Vol. 154, 2008, pp. 9-20. doi:10.1016/j.jhazmat.2007.09.094

[11] P. Molle, A. Lienard, C. Boutin, G. Merlin and A. Ywema, "How to Treat Raw Sewage with Constructed Wetlands: An Overview of the French Systems," Water Science and Technology, Vol. 9, 2005, pp. 11-21.

[12] J. A. Field and R. Sierra-Alvarez, "Microbial Degradation of Chlorinated Benzenes," Biodegradation, Vol. 19, No. 4, 2008, pp. 463-480. doi:10.1007/s10532-007-9155-1

[13] N. Cottin and G. Merlin, "Fate of Chlorinated Benzenes in Laboratory Peat and Pozzolana Filters," Water, Air \& Soil Pollution, Vol. 213, No. 1-4, 2010, pp. 425-435. doi:10.1007/s11270-010-0396-y

[14] C. Rimington, "The Carbohydrate Complex of the Serumproteins. II: Improved Method for Isolation and Redetermination of Structure. Isolation of Glucosamino Dimannose from Protein of Oxblood," Biochemical Journal, Vol. 25, 1931, pp. 1062-1071.

[15] M. Dubois, K. A. Gilles, J. K. Hamilton, P. A. Rebers and F. Smith, "Colorimetric Method for Determination of Sugars and Related Substances," Analytical Chemistry,
Vol. 28, 1956, pp. 350-356.

[16] T. W. Fraser and A. Gilmour, "Scanning Electron Microscopy Preparation Methods: Their Influence on the Morphology and Fibril Formation in Pseudomonas fragi.," Journal of Applied Bacteriology, Vol. 60, 1986, pp. 527533. doi:10.1111/j.1365-2672.1986.tb01092.x

[17] N. Reiche, W. Lorenz and H. Borsdorf, "Development and Application of Dynamicair Chambers for Measurement of Volatilization Fluxes of Benzene and MTBE from Constructed Wetlands Planted with Commonreed," Chemosphere, Vol. 79, No. 2, 2010, pp. 162-168. doi:10.1016/j.chemosphere.2010.01.017

[18] S. Vainberg, C. Condee and S. Robert, "Large-Scale Production of Bacterial Consortia for Remediation of Chlorinated Solvent-Contaminated Groundwater," Journal of Industrial Microbiology \& Biotechnology, Vol. 36, No. 9, 2009, pp. 1189-1197. doi:10.1007/s10295-009-0600-5

[19] B. Vu, M. Chen and R. J. Crawford, "Bacterial Extracellular Polysaccharides Involved in Biofilm Formation," Molecules, Vol. 14, No. 7, 2009, pp. 2535-2554. doi:10.3390/molecules 14072535

[20] T. Narancic, L. Djokic, S. T. Kenny, K. E. O’Connor, V. J. Radulovic, J. Nikodinovic-Runi and B. Vasiljevic, "Metabolicversatility of Gram-Positive Microbialisolates from Contaminated River Sediments," Journal of Hazardous Materials, Vol. 215-216, 2012, pp. 243-251. doi:10.1016/j.jhazmat.2012.02.059 